\title{
Boko Haram Sect: Terrorists or a Manifestation of the Failed Nigerian State
}

\author{
Salihu Mohammed Niworu ${ }^{1}$ \\ ${ }^{1}$ Department of Political Science, Faculty of Management and Social Sciences, Ibrahim Badamasi Babangida \\ University, Lapai, Niger State, Nigeria \\ Correspondence: Salihu Mohammed Niworu, Department of Political Science, Faculty of Management and \\ Social Sciences, Ibrahim Badamasi Babangida University, Lapai, Niger State, Nigeria. Tel: 803-598-3879. \\ E-mail: smniworu2120@yahoo.com
}

Received: March 30, 2012 Accepted: April 11, 2012 Online Published: May 30, 2013

doi:10.5539/jpl.v6n2p245 URL: http://dx.doi.org/10.5539/jpl.v6n2p245

\begin{abstract}
The arbitrary, absolute and statist posture of colonialism permeated the Nigerian society even after 50 years of independence. The change of guards from the colonial lords to the indigenous selected Nigerians did not change the operations of the state. State still remain an instrument of coercion, exploitation and domination. Basic necessities of life, the core of national security eluded the masses. The state became insensitive to the physiological needs of its citizens thereby creating an atmosphere that became beneficial for ethnic and religious chauvinism in Nigeria. The failure of the state gave rise to terrorist groups in all regions of the country. These groups includes, the Boko Haram of the North, the Odua people's Congress of the South west, the Niger Delta Militants of South South and the Massop of the South East. This paper therefore examined the terrorism of Boko Haram sect through the instrumentation of interviews, video and audio tapes, Newspapers, magazines, textbook and internet materials. The paper conclude that in as much as Boko Haram sect are terrorists, and a threat to national security, the Nigerian state has also failed in the provision of the basic needs of the people. The paper recommends among other things that national leadership should be sincere in the provision of basic needs of the citizenry and sign diplomatic treaties that are of immense benefit to Nigeria.
\end{abstract}

Keywords: state failure, collapse of values, primitive accumulation, foreign strategic interest, insurgency

\section{Introduction}

So many things are wrong with the Nigerian state. The economy, the polity, the legal system, education, diplomacy, cultural, moral, religious and family values are all clamoring for reforms. This might raise some fundamental questions as regard the multitude of reforms carried out in post colonial Nigeria during the military dictatorship to 2011 when this paper was written. It is however, sufficient enough to say that they are reforms significantly anchored on the hangovers of colonial past master minded by the existing offspring's of the colonial lords in the metro poles. To understand this phenomenon, one must first understand colonialism and its deep tap roots implanted in Nigeria. The absolute and arbitrary dictation of the above sectors of the Nigerian political economy by colonialism and its antecedent result of insurgency, rebellion, poverty, ethnic and religious chauvinism on the part of the masses, and greed, deceit, collaboration, exploitation and unfulfilled promises on the part of the ruling elites have impacted negatively on the Nigerian society.

This predicament cannot be divorced from the statist posture of colonial experience. The Colonial lords having ulterior motive made state very central in the production process of the Nigerian political economy. The colonial regime was so regulated that they determine what to produce, where and when. They determine what to be taught and learn in schools and the category of black personnel to be employed as subordinate to the whites regardless of their level of training. Ake (2001) commented on the absolutism and the arbitrariness of colonialism in this way...

The colonial state redistributed land and determine who should produce what and how. It attended to the supply of labour, some times resorting to forced labour. It churned out administrative instruments and legislated taxes to induce the breakup of traditional social relations of production, the atomization of society and the process of proletarization. It went into business of education to ensure that workers could do the jobs they were required to perform and 
would remain steadfast in the performance of their often tedious and disagreeable task. It builds roads, railways, and ports to facilitate the collection and export of commodities through commodity boards. Indeed, it controlled every aspect of the colonial economy tightly to maintain its power and to realize the economic objective of colonization.

Evidently, coming from the above background, Nigerian state in the post colonial epoch can only be differentiated from the colonial era by the managers of the state, but the character of the state remained unchanged. The natives that graduated from the colonial tutelage maintained the central posture of state in the production process. Ake (2001) saw state in post colonial Nigeria as an apparatus of violence, totalistic in scope and constituting state economy with a narrow social base and seek for compliance by coercion rather than authority. Apparently, because the state was made central in the political economy, the struggle for power by all means became inevitable making lawful political competition an illusion which eroded the laws of the game and compromise.

It is against this backdrop that ethnic and religious militants sprang up in Nigeria cutting across ethnic, religion and regional backgrounds. It is on record the existence of Massop of the south East clamoring for Biafran republic and Igbo presidency, the Niger Delta Militants agitating for resource control, the Odua People's Congress, of the South West asking for sovereign national conference, the Boko Haram of the North asking for societal reform using the methods of the dissident Kwarijites of prophet Muhammad era. The evolution, sponsor, operation and sustenance of these groups unleashing terror on innocent Nigerians and foreigners is not unconnected with the search for political power, a sure avenue to economic power and influence in the society.

\section{Theoretical Framework and Conceptualization}

This paper is situated within the framework of instrumentalism. While ignorance and greed may dictate some aspects of terrorism, a significant explanation may have to be sought in government policies orchestrated in state institutions. Miliband (1989) sees the state in the advance capitalist formations functioning to maintain the economic and social relation under which bourgeoisie accumulation take place. While in the periphery of capitalism, he outlined factors such as level of development of the productive forces through its several institutions and apparatuses as a direct instrument for accumulation of surplus by the dominant class. The post colonial state becomes an organized instrument of the indigenous dominant social class (Fadakinte, 2002). On the other hand too, state institutions of Europe and America help in provoking terrorism.

If we accept the simple definition of politics as an exercise in determining access to societal resources by variety of socio-economic strata of the society, it is therefore significant to see how the political process equally stimulate poverty and crisis. The state in Nigeria determines who get what, when and how as well as other developmental resources especially material issues. Government exists for the common good of the society, when people surrender their power to a constituted authority, they expect good governance and service delivery to all and sundry. The reverse is the case in Nigeria where endemic poverty side by side with chronic illiteracy and near complete absence of government presence in most communities leading to youths restiveness (Niworu, 2010). Molien (2001) argued that, it is not a matter of hard work or the socio-cultural group one belongs to, but rather which divide of the power bloc one belongs to. The state is exemplified as the ruling elite while organs of government are simply there to reinforce their will. Policies of these organs tend to create poverty and crisis in the society.

The rural peasant masses and the urban poor in Nigeria would continue to live in perpetual poverty because of the crisis inherent in the Nigerian state. Ekekwe (1986) commented that the crisis would continue to linger on because the dominant class instead of first acquiring economic Power and then use it to acquire political power, they were directly given political power by the whites. As such the state became a source of economic power for the dominant group at the detriment of the greater proportion of the peasantry. Access to state resources created a strong basis for enriching the bureaucratic bourgeoisies which fortified that class as an economically powerful class. In the same vein state actions in the western world and America are determined by the urge for economic power and dominance in the world community.

Given this background, what then is state? State as conceived by Sodaro (2001) is the totality of country's governmental institutions and officials. It possesses the legal authority to make laws and enforce it on the population. This definition incorporates all government officials and agencies from the highest officer of the national government to the lowest officer at the local level. Heywood (2000), and Niworu, (2007) conceived state as an instrument for solving peoples collective problems and funded at public expenses. It protects people against external attack and maintains internal peace and order. They provide economic and technological 
progress, social, security and group identity. By implication, the power of the state applies on every member of the society.

Dokken (2008) said there are certain functions states have to undertake successfully in order to be a full fledged entity. For example the security of its inhabitants, the legitimacy and representatives of its rulers, its redistributive functions and the administration of general justice to its citizens. It is these attributes or the urge to acquire them that can judge the success or failure of a modern state. Malliken and Krause (2002) saw the three core activities of the state in providing security, representation and welfare as the main function a state is expected to perform.

A state is a failed state when the basic functions of the state are no longer performed or one that has few or no functioning state institutions that can confer identity and assure security to the population (Zartman, 1995) Francois and Sud (2006) Dokken (2008) cited U.S government state failure taskforce saying state failure is a widespread internal conflict of various kinds such as revolutionary wars, ethnic wars, adverse regime changes, genocide and politic ides.

On the other hand, terrorism cannot be discussed in isolation from fundamentalism. Terrorism shoots out of extreme attachment to ideas or cultures. Fundamentalism therefore is an attitude, an effort or a movement which adheres to or tries to promote its own fundamentals. For example Yunus in answers.com (2008) said when we speak of a free market economy and private ownership of property, we are talking of the fundamentals of modern capitalism. Those who conduct their economic affairs in this way are called capitalists. The same thing goes with religion. The adherents of religious fundamental principles are called fundamentalists whether Christians, Jews or Muslims. Fundamentalism therefore is the core of what the followers of an ideology believe in and are expected to practice it.

Against this background, terrorism can be conceptualized as the unlawful use or threatened use of force or violence by a person or an organized group against people or property with the intention of intimidating or coercing societies or governments often for ideological or political reasons. It is a systematic violence to create a general sense of fear in a population in order to achieve a political objective. It is a political tactics that uses threat or violence usually against civilians in order to frighten a target group into conceding to certain political demands. (Asnwers com, 2008). Terrorism is a violence influenced by political and ideological motives. Weinberg and Eubank (2006) cited Peter Kropotkin, an anarchist of the $19^{\text {th }}$ century defining terrorism as propaganda by deed.

However, state terrorism is the typical cause of terrorist groups where ever they are found. The Nigerian states use her institutions to impoverish its citizens and unleash terror on them through its coercive instruments, the army, the police, the anti graft agencies of Economic and Financial Crime Commission (EFCC). The Independent Corrupt Practices Commission (ICPC) and the bureaucratic bottle necks. These draconian actions of the Nigerian state made national security elusive and in total divergence from president Obasanjo's conception of National security to mean, strengthening the federal republic of Nigeria, advance her interest and objectives; control crime, eliminate corruption, enhance genuine development, progress and growth and improve the welfare, wellbeing and quality of life of the citizenry. In a more realistic perspective, Gwarzo (1998) conceived National Security as freedom from hunger or freedom from threat to a nation's ability to protect and defend itself, promote its cherished values and interest and enhance the wellbeing of its people. Where this is not obtainable people device criminal avenues of fending for themselves.

\section{The Evolution of Boko Haram}

Jama'atu Ahlis Sunna Lidda'awatiwal Jihad Popularized by both domestic and foreign media as Boko Haram is an offshoot of Maitasine group that terrorized Kano state in the early 1980s. It is an ideology inherited by Mohammed Yusuf from his biological father who was an active member of Maitasine group. His hardened mind is not unconnected with his background. His father Mallam Yusuf migrated from Dagira in Niger Republic and his mother from Gashua, Yobe state of Nigeria. He was charismatic, eloquent stubborn, deceitful and always want to impress people. He was an orator and naturally gifted, but not very vast in Islamic knowledge and jurisprudence. (Albani, $5^{\text {th }}$ August, 2009 video conversation).

It was an ideology that has no place in Islam and all the notable Islamic clerics of the Northern Nigeria in the ranks of late Shiekh Jafar Adams Kano, Sheikh Albani Zaria, Sheikh Hudu Yobe etc warned him to desist from its propagation. On the surface, he accepted their advice and within him he continue to gather momentum until 2002 when his ideas became glaring under the pretext of teaching pure Islamic education and values devoid of western cultures. He was initially alternating between Yobe and Maiduguri and finally settled in Maiduguri. He was accommodated in Maiduguri by one of his disciples Mallam Kaga, a serving commissioner of religious 
affairs in Borno under Governor Ali Madu Sherif's government and three times Local Government Chairman. Mallam Kaga gave him a mighty structure where he established his base with a School, a Mosque, Health Facilities and a Training Camp.

Importantly, with a permanent base and financial support coming from that commissioner, he began to spread his ideas in all the nook and crannies of North Eastern Nigeria. His power of tongue can move mountains. With these attributes, he was able to mobilized, influenced and convinced a large army of illiterates, semi literate and literate energetic youths cutting across gender. Infact, Sheikh Albani video edited discussion of 2009 said he was able to charge and over charged youths to dead.

His ideology opposes western education, cultures and sciences. He has neither gone to the four walls of any formal western institution of learning. However he has benefited from the product of western education because he has been in the pay roll of Yobe State as a board member of religious affairs. He attempted to forge secondary certificate through Sheikh Hudu, in Yobe State to enable him enroll for university education.

Sheikh Jafar Adams gave security agents early warning to nip him in the bud, if not three tankers load of water can not quench him. Given the failed state institutions, nothing was done until he became confrontational with the state. It is pertinent to note that, 2010 through 2011 North Eastern states of Nigeria and the Federal Capital recorded several bomb explosions killing several innocent citizens both civilians and armed forces. The highest security officer Hafiz Ringim, Inspector General of Police escaped this attack narrowly on the $17^{\text {th }}$ of June, 2011 when the police headquarters was bombed by Boko Haram. Prior to the attack that engulf the police headquarters, in January, 2010, Dala Alemderi ward of Maiduguri was attacked killing four people. On September $7^{\text {th }} 2010$ they raided Bauchi prison and freed close to 1,000 prison inmates. In December, 2010, Maiduguri market was bombed on the $28^{\text {th }}$ of January, 2011, a gubernatorial candidate of ANPP in Maidugiri was assassinated with his brother and four police officers. This bombing does not preclude selected gun shots at security agents and Islamic clerics in Maiduguri .On the $16^{\text {th }}$ of April,2013 the Boko Haram sect clashed with security agents in Baga, Borno State leaving over one hundred and eighty (180) people dead

\section{Mohammed Yusuf, American Strategic Interest and the Perception of Northern Nigerian Muslims}

Islamic religion, education and civilization predate western education and civilization for about 400 years. It teaches all aspects of human endeavour be it law, politics, economy, governance, security, diplomacy, human relations etc. It does not encourage violence but rather equality and justice. This is very evident in its legal provision that an eye should be taken in revenge for an eye. It is in this vein that Mohammed Yusuf was seen by Islamic clerics of the North as a stooge been used by Americans through their CIA members in Nigeria to erode the state monopoly of force to pave way for the establishment of their military base in Nigeria. The countries of central Africa sharing boarders have had several crisis perpetuated by foreign sponsors to enhance their strategic interest. The Gulf of Guinea has been the interest of America and therefore could instigate conflict in the region. This region has abundant oil, gas and other minerals. The oil from Gulf of Guinea has comparative advantage over that of latin America and elsewhere. The crude oil has better quality than that of latin America with API gravity of above $30^{\circ}$ to $40^{\circ}$. API gravity is a scrods that shows the gravity or density of liquid petroleum products. Oil from this region contains little sulfur by the international standards very much appreciated by American Oil Companies. There is ease in shipping it with lower transportation cost and less environmental hazard. Apart from oil, gas and other minerals endowment of the region, United States of America and the whole of Europe attaches great political importance to the Gulf of Guinea particularly in their attempt on the surface to police the world. The aftermath of 9/11 2001 coupled with the ulterior economic motive influenced America to have counter terrorism military base in strategic states of gulf of guinea. The United States of America intend to establish these military base in Muslim dominated countries of sub-Saharan Africa specifically Nigeria, Niger Republic, Chad, Mali, Mauritania (Godwyn and Morrison in Mane, 2005). A terrible insinuation attributed to an American ambassador that Nigeria would disintegrate is a clear pointer that a foreign power is behind Mohammed Yusuf. This is truism if not why should Jery Gana, a Christian fundamentalist bail Mohammed Yusuf when he was first arrested.

In the words of Dokken (2008), the world has changed since the end of the cold war. There is now an increasing threat to international community as a whole linked primarily to terrorism, threats against the individuals, against his or her physical survival, human rights, basic welfare rights and threat to countries at regional level. He stressed further that the western countries have been the target of terrorist, but Africa have been the most important breeding places. He said West Africa contains eleven out of the world's twenty five poorest countries and currently one of the most unstable regions of the world. 
In reactions to the spate of bombing of Boko Haram, the Muslims of Northern Nigeria became divided along two divergent poles. The few knowledgeable Muslim clerics and the intellectuals of western education stand against the ideology of Mohammed Yusuf as opposed to the large majority of ignorant Muslims who saw Mohammed Yusuf as an hero fighting the injustice and deprivations of the Nigerian state. Sheikh Jafar Adams Kano said in Albani (2009) that Boko Haram is an orchestrated plan whether within or outside to perpetually set the North backward by sponsoring Mohammed Yusuf to further propagate his ideology that western education is inimical to Islam so that the urge of the North to catch up with the south in western education would be an illusion.

\section{Conclusion}

This paper concludes that Boko Haram is a major terrorist outfit that operated in a conducive atmosphere created by the failure of the Nigerian state. The insensitivity of Nigerian state to the plights of the masses has created an atmosphere that became beneficial to ethnic and religious war lords with resultant effect of threat to National security. The enormous resources of the country have no trickle down effect on the mass population of the country both in the rural and urban centers. People have become government unto themselves. They contribute money to pay vigilante for their security. They provide their drinking water, health needs, buy generators to provide light and in most cases pay with their dear life. Against this backdrop, this paper recommends that Nigerian leaders should be sincere in the delivery of service to the people. It is on records where leaders entrusted with people's mandate and fund diverts such fund for personal riches.

National leaders should be sincere in their romance with Europe and America. Diplomatic relationships should be anchored on mutual benefit for Nigeria. They should stop doing the white masters job to sustain their relevance at the detriment of the country. There should be massive investment of resources in education not only in the North, but the whole country. This will increase manpower in the tertiary sector of the economy thereby enhancing service delivery and reduce over dependence on the primary sector of the economy. Northern Muslim with dogma of static thoughts should expunge it. There is the utmost need for social justice. Give all shades of opinion a fair hearing before prosecution. The wealth accruing to the nation should have a trickle down effect on the masses.

\section{References}

Ake, C. (2001). Democracy and Development in Africa. Ibadan: Spectrum Book Ltd.

Albani, Z. (2009). Video clip recorded on 5th August, 2009 at Salafiya Islamic Center Zaria.

Dokken, K. (2008). African security politics redefined. New York: Palgrave. http://dx.doi.org/10.1057/9780230612495

Ekekwe, E. (1986). Class and state in Nigeria. Lagos: Longman.

Fadakinte, M. M. (2002). The Nigerian state and Transition politics. In B. Onuaha, \& M. M. Fadakinte (Eds.), Transition politics in Nigeria 1970 - 1999. Lagos: Malt House press Ltd.

Francois, \& Sud. (2006). promoting stability and development in Fragile and failed states. Development Review, 24(2), 141-160.

Gwarzo, I. (1998). Meeting the Current Challenges of National security. Abuja: National war College.

Heywood, A. (2000). Politics. New York: Pal grave.

Mane, D. O. (2005). Emergence of the Gulf of Guinea in the Global Economy: Prospects and Challenges. IMF working paper (accessed, $8^{\text {th }}$ August, 2011).

Miliband, R. (1969). The state in capitalist society. London: Weiden field and Nicolson.

Miliken, J., \& Krause, K. (2000). State failure, state collapse and state Reconstruction, lessons, and strategies. Development and change, 33(5), 752-774.

Molien, M. (2001). The state and survival. Makere University Press.

Niworu. S. M. (2010). Poverty, Politics, and Labour Export in Nigeria: A Study of Girl Child Labour Export in Mokwa Local Government, Niger State. (Unpublished Ph. D. Thesis). Department of Political Science, Bayero University, Kano.

Niworu, S. M. (2007). Man and his Government. A conceptualization. Minna: Elicola Printing Press.

Sodaro, M. J. (2001). Comparative politics. A Global Introduction. New York: McGraw Hill.

Terrorism. (2008). Retrieved October 4, 2008, from http://www.answers.com/topic/terrorism 
The myth of Islamic fundamentalism. (2008). Retrieved September 24, 2008, from http://www.genocities.com/collegepark/6453/myth. htm

Weinberg, L., \& Eubank. (2006). What is Terrorism. New York: Chelsea House Publishers.

Zartman, I. W. (Ed.). (1995). Collapse states: The disintegration and Restoration of legitimate Authority. London: lynne Rienner.

\section{Copyrights}

Copyright for this article is retained by the author(s), with first publication rights granted to the journal.

This is an open-access article distributed under the terms and conditions of the Creative Commons Attribution license (http://creativecommons.org/licenses/by/3.0/). 